\title{
The Use of Data in the Making and Monitoring of Parental Leave in Australia
}

\author{
Marian Baird ${ }^{(D)}$, AO, Professor of Gender and Employment Relations
}

University of Sydney, NSW, Australia

\begin{abstract}
This paper considers the availability and use of data in parental leave policy making and monitoring in Australia. The terminology of parental leave is discussed and its use in Australia is explained as referring to paid and unpaid leave for mothers, fathers and partners at the time of birth or adoption of a child and usually covering the first 12-24 months after the birth or adoption. It includes entitlements in labour law legislation, the federal government's Paid Parental Leave scheme and separate employer provisions. The paper outlines the range of data sources and how they were used to construct a case in favour of the introduction of the Paid Parental Leave scheme in 2010 and to monitor its implementation, as well provision of paid parental leave through enterprise bargaining and company policies. The paper also explains how data was used in a deliberately constructed way to defend the Paid Parental Leave scheme when it was under threat of significant change. In conclusion, the paper draws attention to the way terminology is shifting, to how data illuminates the gendered use of parental leave in Australia and argues for the need for refreshed data on parental leave availability, access and use in Australia.
\end{abstract}

Keywords - parental leave; maternity leave; dad and partner pay; primary carer leave; secondary carer leave; gender equality.

Acknowledgments: No grants were used in writing this paper.

Disclosure statement: No potential conflict of interest was reported by the author.

License: This work is under Attribution-NonCommercial-ShareAlike 4.0 International (CC BY-NC-SA 4.0)

https://creativecommons.org/licenses/by-nc-sa/4.0/

Suggested citation: Baird, M. 2021. "The Use of Data in the Making and Monitoring of Parental Leave in Australia." Law in Context, 37 (2): 62-73, DOI: https://doi.org/10.26826/law-in-context.v37i2.163

\section{Summary}

1. Parental Leave Policy in Australia: A Brief introduction

2. Definitions and Overview Australia's Paid Parental Leave Scheme

3. Paid Parental Leave and the Data Landscape

4. Data on Employers and the Provision of Paid Parental Leave

5. Use of Data to Defend the Scheme

6. Conclusions

\section{PARENTAL LEAVE POLICY IN AUSTRALIA: A BRIEF INTRODUCTION}

The focus of this paper is the availability and use of data for parental leave policy making and monitoring in Australia, including both the unpaid and paid elements of the policy and employer provisions. The origins of unpaid parental leave entitlements date back to 1979, whereas paid parental leave is a relatively recent policy, 
with the passage of the Paid Parental Leave Act 2010 (Cth) by the Rudd Labor Government. This Act introduced for the first time federally funded parental leave pay that was accessible to a majority of Australian working mothers and was especially important to women in low paid sectors of the economy who as the data clearly showed at the time, did not receive any paid parental leave from their employers. The Paid Parental Leave Act marked a significant addition to the social policy portfolio in Australia (Baird and Williamson 2011).

Introducing a new piece of social policy is usually a highly political process and the use of data in arguments for the introduction and design of the paid parental leave scheme was one important part of the process. In the ten years since its introduction the scheme has been comprehensively evaluated (see Martin et al 2014b), amended in 2012 to provide two weeks Dad and Partner Pay (DaPP), threatened with a major redesign which would have reduced the financial value to many working women, and most recently in 2020 amended to allow greater flexibility in use for mothers and fathers (Baird and Hamilton 2021).

The paper is organised as follows. Following this introduction, section 2 provides definitional clarification of parental leave. Section 3 reviews the Paid Parental Leave scheme and the sources of data that have been used to design and monitor it. Section 4 examines the available data on employers' provision of maternity, paternity and parental leaves, or as they are also referred to, primary and secondary carers leave. Section 5 then presents a case of how the Government scheme was defended using data in a particular way, and section 6 concludes with some comment on the gendered use of parental leave, current gaps in data and the need for refreshed data.

\section{DEFINITIONS AND OVERVIEW AUSTRALIA'S PAID PARENTAL LEAVE SCHEME}

The term parental leave is used differently in Australia than many other countries, so it is necessary to define and differentiate the terms that are most used, as they

\footnotetext{
${ }^{1}$ Note that New Zealand also call their scheme 'parental leave'.
}

have become somewhat of a confusing policy and data space in themselves. Possibly the most definitive source on parental leave globally is from the International Leave Network who define parental leave as 'Leave available equally to mothers and fathers' (Koslowski et al. 2020, p. 6). In Australia, although called 'parental leave', the legislation is written so that the provision is not available equally, but is first available to the mother, who may then pass it to a secondary (usually father or partner), or even tertiary (perhaps a grandparent carer).

Maternity leave, as the name suggests, refers to leave reserved exclusively for mothers. In most countries it is usually a short, specified period close to the birth (or adoption) of a child. In Australia unpaid maternity leave of 52 weeks with a job guarantee on return was made available to award covered employees in 1979. This right to unpaid parental leave remains a critical foundation plank of parental leave in Australia and to the operation of the federal government's scheme, which does not give leave but provides pay. Through two subsequent test cases before the Australian Industrial Relations Commission the leave was later made available to adoptive mothers in 1980 and fathers in 1990 , when the name was changed to parental leave (Baird, 2005). Unpaid parental leave of 12 months is now available to each working parent as one of the National Employment Standards of the Fair Work Act 2009 (Cth), which also affords an employee the right to request their employer for a further period of unpaid parental leave (up to a maximum of 12 months) by accessing the other working parent's unused quota. Paternity leave, as with maternity leave, refers to a short period of leave reserved for the father at or around the birth of a child. In summary, in Australia, policy naming conventions have moved away from naming the leaves explicitly maternity or paternity leave and use the generic 'parental leave' for all forms of leave relating to parenting, which is different to most countries. ${ }^{1}$

In addition to the use of the term 'parental' leave in policy, and in an attempt to not pre-determine gender 
use, the terms 'primary carer's leave' and 'secondary carer's leave' have become more widespread at company policy level and in collecting data from employers. These terms are used in two of the most widely referenced data sources of employer provision, the Workplace Gender Equality Agency's data collection and the Workplace Agreements Database, both of which are discussed further below. However, there is also criticism of these terms among equality advocates, as the terms still suggest an unequal division of care between the primary and secondary carer, and by implication promotes this unequal division. As the asymmetric provision of care (Shaver 1999) continues to be a feature of Australia's care system more broadly, it is not clear that a simple relabelling will shift behaviours. The continuing low take-up rates among fathers of 'parental leave', both paid and unpaid, as the data show, suggests that different naming conventions are not enough to change behaviours (Whitehouse, Baird, Diamond and Hosking 2006; Baird, Hamilton and Constantin 2021). On the other hand, explicit policy design that opens the leave to either parent and encourages men to use parental leave, as some companies are doing, may result in more fathers and partners taking leave. The research clearly demonstrates that a more gender equitable uptake of parental leave only occurs if there are incentives for fathers to use the leave, such as high wage replacement rates and ring-fenced leaves, and if the career penalties of taking parental leave and negative workplace care cultures are removed (O’Brien 2009; Haas and Hwang 2019).

\section{PAID PARENTAL LEAVE AND THE DATA LAND- SCAPE}

The national Paid Parental Leave scheme as it currently operates in Australia, provides 18 weeks at the National Minimum Wage (NMW) to the primary recipient (overwhelmingly the mother as the data described below show) and two weeks Dad and Partner Pay (DaPP) to the father or same-sex partner, also at the NMW. There are three eligibility criteria for the paid parental leave, based on residency, work and income.
At the turn of the millennium, when the paid parental leave campaign was gathering momentum, evidencebased policy making was a guiding philosophy, and as the Productivity Commission noted, '[S]ystematic evidence-based analysis is an essential element of all good policy' (Productivity Commission 2013). But initially there was only patchy Australian data or evidence on paid parental leave. As was argued by Whitehouse, Baird and Soloff (2007, p. 1) 'Information on the uptake of parental leave policies and the work experiences of parents prior to and following the birth of a child is extremely limited in Australia.' An earlier study of Australian women was undertaken by Helen Glezer in 1986 and those results showed that taking maternity leave was rare for Australian women. Although more common in the public sector it was especially unusual for women in the private sector to take maternity leave (Glezer 1988). In order to address these data gaps a survey, led by Professor Gillian Whitehouse, was undertaken. 'The Parental Leave in Australia Study' (PLAS), collected valuable data on both access to and use of unpaid parental leave and paid parental leave by mothers and fathers. The PLAS results showed a very gendered use of the leave that was then available, with women accessing unpaid parental leave for up to 35 weeks and men using annual leave and very short periods of paid parental leave, generally of 7 days. The results demonstrated 'the very different patterns of leave-taking among mothers and fathers at the time of their child's birth.' (Whitehouse, Baird and Soloff 2007, p. 109). Other research indicated that women in certain industries, such as the highly feminised retail and hospitality sectors, had little or no paid parental leave provided by their employer (Baird 2003). These results showed major gaps in access to this entitlement, often related to lower skill and pay levels of women and a great deal of gender inequality in use of parental leave, unpaid and paid.

It became clear that, as well as community and union support, improved data was needed to prosecute the case for improving Australia's paid parental leave provisions. At the time (early 2000s), for a mix of political, 
historical and social reasons, the argument was focused on gaining paid maternity leave. In 2002 the Human Rights and Equal Opportunity Commission (HREOC) recommended to government a paid maternity leave scheme of fourteen weeks duration, to be paid at the national minimum wage (HREOC, 2002_a and b), but it was not until a change of government with the election of Labor in 2007 that the matter was referred to the Productivity Commission and the economic case was strongly argued and became accepted as a rationale for introducing the Paid Parental Leave Act in 2010.

The architecture of the scheme was heavily influenced by the Productivity Commission who, at the request of the federal Labor government, conducted an extensive inquiry into the costs and benefits of introducing a scheme. After analysing considerable amounts of data and submissions, the Productivity Commission recommended 18 weeks parental leave pay funded from general revenue, noting that 'there is no exact science about choosing the precise duration' (Productivity Commission 2009, XXI). The Commission saw an ongoing role for employers in being the 'paymasters' and in time, providing superannuation (Productivity Commission 2009, XIV). The Productivity Commission's report also estimated, using Australian Bureu of Statistics' (ABS) figures, that 54 per cent of female employees and 50 percent of male employees have access to employerprovided paid parental leave', but that this was not likely to increase over the following decade without a scheme (Productivity Commission 2009, XVI).

There are now various sources of data available to show access and use of parental leave in Australia. The ABS Pregnancy and Employment Transitions Survey, (PaETS) undertaken every six years and last in 2017, reports that ' $[\mathrm{t}]$ he proportion of women who worked as employees while pregnant and took leave (paid and / or unpaid) was relatively unchanged (93\% in 2017 versus $92 \%$ in 2011). Of these women, the share who reported taking unpaid leave dropped from $71 \%$ in 2011 to $65 \%$ in 2017.' This data suggests that by 2017 a high proportion of employed women had access to some form of paid parental leave, a notable improvement on the Productivity Commission's 2009 estimates. Although these figures do not distinguish between employer provided and government provided payment, the increase in provision can be attributed to the federal government's scheme, because as explained below, around fifty per cent of employers still do not provide paid parental leave.

The introduction of the federal government's Paid Parental Leave scheme was a major shift in policy and to assess how the scheme met its objectives, the Department of Families, Housing, Community Services and Indigenous Affairs (FaHCSIA) commissioned the evaluation of the Paid Parental Leave scheme. This was conducted by a multi-disciplinary team of academics, led by the late Professor Bill Martin, at the Institute for Social Science Research at the University of Queensland. This evaluation provided four comprehensive reports, covering the impact of the scheme on mothers, infants and employers, as well as the administrative processes (see Martin et al. 2012, 2013, 2014 a and b). The phase 4 report concluded that the paid parental leave scheme was for the most part achieving its objectives: it enabled women to spend more time away from paid work following a birth or adoption, especially so for self-employed mothers and lower income mothers (addressing a key gap in provision identified by earlier studies), increased retention rates and improved the average physical and mental health of mothers. However, the review reported 'mixed evidence' on the impact on gender equality (Martin et al. 2014b, pp. 4-9).

Another source for information about the use of the Government PPL and DaPP schemes has been the annual reports of the Department of Social Services (DSS) (formerly the Department of Families, Housing, Community Services and Indigenous Affairs (FAHCSIA)) which draw on administrative data: 'data that has been collected from the operation of administrative systems for services provided by the government or community agencies' (Spallek et al. 2020, p. 467). The DSS reports contain only selected data from the full administrative data available to government, so there are gaps in information. Additionally, the reporting of data has also slightly changed over the years making year on year comparisons difficult to follow. Table 1 provides a 
summary of data collated from annual reports since the scheme began, showing that approximately half of all mothers who gave birth in a year receive parental leave pay from the government. The other half presumably do not meet the required work, income or residency tests, but which aspects are not known. It is unclear from these reports how many mothers transfer their payment to their partner (or other party). The data reports the number and percentage of fathers and other partners who have taken the full two weeks of Dad and Partner Pay, but it is not known what proportion of all fathers or partners in Australia use this scheme, in full or in part in any given year. For equality and transparency reasons it would be very useful to have more information, for example, about whether mothers transfer their payment and to whom, and their income levels; and more information on fathers or partners who access the Dad and Partner Pay.

Access to parental leave is one key dimension of most data analyses and use or uptake of the leave is another key dimension. Both data indicators are used to provide some insight into the equality of schemes, especially in relation to gender and class. Other frequently used indicators in Australia and internationally are eligibility criteria, pay rates and incentives to share the leave between parents (for example, see Whitehouse and Hideki 2021; Ray, Gornick and Schmitt 2010). Further information about length of leave taken and return to work rates by mothers have also become important to policy makers as attention has increasingly focused on the labour force engagement of childbearing age women (Baird and O'Brien 2015). In more recent years as debates about gender equality in the provision of care have intensified, the focus of advocates and policy makers has turned to the use of parental leave by fathers.

\section{DATA ON EMPLOYERS AND THE PROVISION OF PAID PARENTAL LEAVE}

With the Productivity Commission acknowledging the role that some employers were playing, the two-tier design of employer provided paid parental leave plus the federal government scheme followed the history of parental leave policy in Australia (See Baird 2005 for an overview of the role of the industrial relations system and employers in parental leave.) The resulting situation is that Australian working mothers and fathers potentially have access to two forms of paid parental leave - from the federal government scheme (if they meet the eligibility criteria) and from an employer scheme, if available to them. There are a variety of data sources on employer provided paid parental leave, with some variation in timing and questions asked, and therefore data obtained.

The ABS Pregnancy and Transitions survey (referred to above) is undertaken every 6 years and asks respondents a number of questions about their access to and use of employer paid and unpaid maternity leave, as well as their eligibility for and use of the Paid Parental Leave Scheme. ${ }^{2}$ It also asks them about their partners' use of parental leave and the Dad and Partner Pay. The Household, Income and Labour Dynamics in Australia (HILDA) ${ }^{3}$, is a house-hold panel survey conducted since 2001 and provides information on a range of parental

\footnotetext{
${ }^{2}$ The ABS Pregnancy and Transitions survey questions: 'Does your employer provide you with paid maternity leave?'; Did you take any paid maternity leave for [child's name]'s birth? Was this maternity leave taken at full-pay, half-pay or both? How many weeks of maternity leave at full-pay did you take? How many weeks of maternity leave at half-pay did you take? Are you on this paid maternity leave now? What is the main reason you did not take any paid maternity leave? Did you take any unpaid maternity leave for [child's name]'s birth? How many weeks unpaid maternity leave did you take? What was the main reason that you did not take any unpaid maternity leave? Are you on unpaid maternity leave now? Were you eligible for Paid Parental Leave (PPL)? Did you receive the Paid Parental Leave (PPL) (to supplement your income) while on leave for [child's name]'s birth? What is the main reason you did not receive the Paid Parental Leave (PPL)? How many weeks of [parental leave/other unpaid leave/parental leave and other unpaid leave] did you take? Are you on this [parental leave/other unpaid leave/parental leave or other unpaid leave] now?

${ }^{3}$ See https://melbourneinstitute.unimelb.edu.au/hilda
} 
Table 1: Government Annual Report Data: Parental Leave Pay and Dad and Partner Pay 2010-2020

\begin{tabular}{|c|c|c|c|c|c|c|c|c|c|c|}
\hline $\begin{array}{l}\text { Number of moth- } \\
\text { ers/parents* for whom } \\
\text { PLP has been paid as a } \\
\text { proportion of all moth- } \\
\text { ers in the same year }\end{array}$ & 43,000 & 124,397 & 131,307 & 144,255 & 158,145 & 169,745 & 170,925 & 159,372 & 178,758 & 171,712 \\
\hline $\begin{array}{l}\text { Number of dads and } \\
\text { other partners who } \\
\text { have taken the full two } \\
\text { weeks of Dad and Part- } \\
\text { ner Pay }\end{array}$ & & & 27,240 & 72,975 & 70,785 & 79,126 & 83,600 & 81,882 & 91,762 & 92,343 \\
\hline
\end{tabular}

*Wording in tables refers to mothers and in annual reports text to parents

Sources: FAHCSIA, 2012, 2013; DSS, 2014, 2015, 2016, 2017, 2018, 2019, 2020.

Table 2: Scenario of impact of proposed changes under the Fairer Paid Parental Leave Bill

\begin{tabular}{|l|l|}
\hline Teacher mum who works part-time (3 days a week) in South Australia. & Part-time \\
\hline Average hourly pay rate & $\$ 40$ \\
\hline Worked hours/week & $\$ 960$ \\
\hline Average weekly earnings & $\$ 1,561$ \\
\hline Average weekly expenditures for a couple with children in South Australia & $\$ 144$ \\
\hline Average weekly cost of child 0-4 yo & $\$ 1,705$ \\
\hline Total average weekly costs (weekly expenditures plus child costs) & 16 \\
\hline Employer PPL weeks (SA Teachers EA) & $\$ 15,360$ \\
\hline Employer PPL total value & $\$ 672$ \\
\hline Current PPL model & 18 \\
\hline Government weekly Parental Leave Pay rate (at the minimum wage, for up to 18 weeks) & $\$ 12,096$ \\
\hline Government PPL weeks & $\$ 27,456$ \\
\hline Government PPL total value & 16 \\
\hline Total current PPL (Government pay topped up by Employer) & 2 \\
\hline Weeks of average living costs covered under the existing model & $\$ 1,344$ \\
\hline Proposed PPL model & $\$ 16,704$ \\
\hline Government PPL in weeks (18 minus weeks of employer provided PPL) & 10 \\
\hline Government PPL total value (weekly rate at minimum wage) & 16 \\
\hline Total new PPL(Government pay \& Employer pay) & $\$ 10,752$ \\
\hline Weeks of living expenses covered under the new cut model & 6 \\
\hline Weeks of PPL income lost under proposed new model & $\$ 16$ \\
\hline Financial loss for the new parent & \\
\hline Weeks of average living costs lost as result of government's PPL cuts & \\
\hline
\end{tabular}


leave items, not all of which are collected in each wave. ${ }^{4}$ The population sub-sample for wave 18 (2018) results show that 60 percent of respondents who could answer the question say they have access to paid parental leave as a workplace entitlement. The ABS and HILDA data can be used to build time series of paid maternity and paternity leave entitlements by a range of individual characteristics.

The two most often referred to data sets for ongoing updates on the availability of paid parental leaves in Australian workplaces are the Workplace Agreements Database (WAD) and the dataset of Workplace Gender Equality Agency (WGEA). WAD is held in the Attorney Generals department and is a register of all federally registered enterprise agreements, with clauses coded and reported on each quarter. The WGEA receives annual reports from all 'relevant employers' (private sector employers with 100 or more employees and higher education institutions) under the Workplace Gender Equality Act 2012 and composes a dataset on gender equality in Australian workplaces. Since 2017 WGEA has asked for information on 'Paid primary carer's leave provided to women and men' and 'Paid secondary carer's leave provided to women and men'.

The 2019-2020 reports show that 52 per cent of employers provide paid primary carer's leave at an average of 11 weeks, and 45 percent provide paid secondary carer's leave an average of two weeks, with men representing just 6.5 per cent of users of paid primary carer's leave (WGEA 2020). From 2021 WGEA's questions to employers have been refined to overcome the primary/secondary carer distinction, and instead they are asked to respond to the following: 'we offer employer funded parental leave (without using the primary/secondary carer definition) or 'we offer employer funded parental leave (using the primary/secondary carer definition)' (Personal correspondence with WGEA, 26 August 2021, emphasis added).

The Workplace Agreements Database (WAD), housed in the Attorney General's Department provides information on paid primary and secondary carer's leave clauses by incidence, duration and estimated employees covered, in all federally registered enterprise agreements. This data is useful for tracking over time changes collective bargaining outcomes between unions and employers ${ }^{5}$, and to trace back to the actual enterprise agreement for the wording of clauses (see Baird, Frino and Williamson 2009). A recent analysis of WAD shows that for paid primary carer leave, 12 weeks is the average duration bargained, and that for paid secondary carer leave it is just two weeks. Further, the proportion of union agreements with a paid primary carer leave clause has shifted from 21 per cent in 2009 to 28 percent in 2019, and for a paid secondary carer leave clause from 15 per cent in 2009 to 22 per cent in 2019 (Baird, Hamilton and Constantin 2021).

Neither the WAD nor WGEA data sources provides the complete picture. The WAD is of enterprise agreements only and estimates number of employees covered by those agreements. It does not break this down by gender, so we cannot be sure of gender differences in access to paid parental leave clauses. The WGEA data set does not cover small businesses and so possibly tends to exaggerate the narrative about business provision of

${ }^{4}$ The HILDA questions relevant to parental/maternity/paternity leave are:

1. Parent took formal maternity/paternity leave (non-resident child) for each child: measured in waves 5, 8, 11, 15.

2. Parent took formal maternity/paternity leave (resident child) for each child: measured in waves $5,8,11,15$.

3. DV (derived variable): Days of paid (maternity, paternity, bereavement, family, carers) leave in last 12 months: measured in waves 5-18.

4. Workplace entitlements: Paid maternity leave: measured in waves $2-18$.

5. Personally entitled to use paid maternity leave in current job: measured in wave 1 .

6. Workplace entitlements: Parental leave: measured waves $2-10$.

7. Personally entitled to use paid parental leave in current job: measured in wave 1 .

8. Workplace entitlements: Paternity leave: measured in waves 11-18.

9. Workplace entitlements: Unpaid maternity leave: measured waves $2-10$.

10. Personally entitled to use unpaid maternity leave in current job: measured in wave 1 .

${ }^{5} \mathrm{WAD}$ also includes non-union agreements. They represent a small proportion of all agreements. 
paid parental leave, as small businesses are less likely to provide paid parental leave. Both sets of data shed similar light on where the inequalities and variations in employer paid parental leaves are to be found. For example, according to the WGEA 'data explorer' site, 25 per cent of employers in the Accommodation and Food Services sector offer paid primary carer leave to both men and women, compared to 81 per cent of employers in the Financial and Insurance services sector, replicating the industry patterns found over a decade earlier. Occupational and industry differences in the provision of paid parental leaves is also marked in enterprise agreements resulting in working women having very different access to paid parental leaves depending on their occupation and industry status. These outcomes produce within gender inequalities (Baird et al. 2009). That is, there continues to be disparity among working women in terms of how much paid parental leave they are entitled to, as women in higher paid sectors tend to also receive more employer provided paid parental leave, whereas those in lower paid positions tend to be reliant on the Government scheme alone. These differences can also be exacerbated by employment type, so that women in casual work may not meet eligibility requirements for either government or employer provided paid leave, thus further increasing the inequalities within the category of working women. In addition, the difference in provision of leave to the secondary carer (typically fathers or partners), built into the government scheme and detected in both enterprise agreements and company policies, reinforces a between gender inequality. The shorter duration of the Government's Dad and Partner Pay and secondary carer's leave in enterprise agreements and employer polices, limits the opportunity for fathers and partners to take parental leave and reinforces the strong maternalism of Australia's system and the resultant highly gendered divisions in care.

\section{USE OF DATA TO DEFEND THE SCHEME}

As seen from the preceding discussion, data is an important contributor to policy making and evaluating. By the same token, knowledge of data sources and their application may also be critical to defending a policy. In this last section of the paper focus turns to one particular episode in the life of the federal government's Paid Parental Leave scheme and the way in which data was used by activists to draw attention to the negative impact of some changes the Coalition Government was proposing, and thus contribute to stopping the passage of these amendments. The proposals by the Coalition government were to amend the scheme first with two amendments the 'Removing Double-Dipping from Parental Leave Pay' budget measure and then with the 'Fairer Paid Parental Leave Bill'. These were put forward between 2014 and 2016 (Taylor 2018). The changes would directly impact working mothers most, because, as the data show, they are the main users of the scheme, and secondly, through the flow on effect, their family or household incomes. The main thrust of the amendments was to cut payments by capping the available combined time for all eligible workers at 18 weeks. Thus, for any mothers who utilised paid parental leave provisions negotiated into their enterprise agreements or provided by their employer's company policy, the equivalent number of weeks would be deducted from their government provided parental leave pay. For example, if the employer provided 8 weeks paid parental leave, the worker would only be eligible for 10 weeks of the Government provided paid parental leave. Forward estimates for 2017 showed the government would save an estimated \$1,179.9 million (Explanatory Memorandum 2016). Women's and parent's advocacy groups were outraged that working mothers were being targeted, especially as one of the design features recommended by the Productivity Commission was a system that allowed for the combination of government and employer provided paid leave of a minimum of 26 weeks, which was considered important for health and welfare reasons for both a baby and new mother. Other language used by Government ministers such as accusing mothers of 'double dipping' and 'rorting' the system inflamed the debate further (Mather 2015). After having to argue for over a decade to get a paid parental leave scheme, to see it being attacked in this way, and by implication women's working conditions being undermined, added further insult.

To stop this proposal passing into legislation one advocacy group, Fair Agenda, commissioned research 
(Baird and Constantin 2016) which set out to calculate the loss to particular types of working mothers and their families through developing scenarios which the public could easily relate to, and to then circulate this information in key marginal seats. These scenarios drew on knowledge of the segmented and gendered nature of the Australian labour market. They were of a retail worker in Tasmania, a part-time nurse in South Australia, a patient transport officer in Queensland and a part-time teacher in Victoria. In addition to calculating the loss, the costings included data on the average weekly earnings of these women, noting whether or not they were full time or part time, average weekly living expenses and the costs of raising a child. All data was sourced from reliable places such as the relevant industry award and the Australian Bureau of Statistics and a methodology was provided to verify the calculations. The scenarios demonstrated that the loss to women in these typical women's jobs, ranged from 6 weeks to 16 weeks of parental leave income and amounted to losses of $\$ 4,032$ and $\$ 10,752$ for these new parents, not insignificant amounts. An example of one such scenario, that of a part-time teacher, is provided in Table 2 .

By providing data in this way and making it available to the general public and key parliamentarians, the Fair Agenda campaign aimed to reframe the debate to one explaining how the policy change would result in significant loss to specific groups of working mothers, and to counter the government narrative which was one of emphasising excessive government payments to high paid women. The aim was not to create new data, but rather to use existing data to convince the voting public of the negative implications of the scheme. The proposed cuts were ultimately shelved, and these financial impact scenarios represented just one dimension of the opposition to the proposal. They are an example of how data can be used in different ways in arguments about social policy.

\section{CONCLUSIONS}

Following the failed attempts to wind back elements of the federal Paid Parental Leave scheme, policy makers and the community seem to have reached the position where the scheme is an integral part of Australia's social policy framework. Rather than downgrading the scheme, the Coalition Government's most recent changes to the scheme have focused on improvements, such as allowing greater flexibility in use. The bigger, and more costly, improvements to provide superannuation and extend the duration of payment have not, however, occurred.

As the paper has shown, there is a wealth of data supporting our understanding that paid parental leave in Australia is parental leave in name, but not in practice, for example data from the Government's DSS annual reports, the ABS, HILDA and WGEA, show that both the unpaid and paid versions of parental leave are used overwhelmingly by mothers. One thing clear from the data is that the use of parental leave is still highly gendered in Australia.

The available data from the WGEA and WAD also indicates the limited reach and generosity of employer provided paid parental leave, with each providing useful but not complete information. There continue to be gaps in knowledge about access to paid parental leave by casual female workers, Indigenous workers and single parents. Another area of inequality and gaps in data relates to use by fathers of parental leave, in either unpaid or paid forms and this is clearly an area of policy that needs attention if more equality between mothers and fathers is to be achieved.

It is now just over ten years since the introduction of the Paid Parental Leave Act, and with the recent moves to make use more flexible, with employers changing their provisions to be more gender equitable as well as shifting community attitudes to fathering, the time has come for a new parental leave in Australia study, one that enables us to capture the extent of the changes, to understand the degree to which women and men are using the unpaid parental leave provision and for how long, and one which covers the multiple layers and details of the various paid parental leave schemes that now exist. 


\section{REFERENCES}

1. Australian Bureu of Statistics (ABS). 2017. "Pregnancy and Employment Transitions Survey" (catalogue no. 4913.0, 29 June 2018).

https://www.abs.gov.au/ausstats/abs@.nsf /mf/4913.0.

Accessed 25/8/2021.

2. Baird, M. and Williamson, S. 2011. "Women, Work and Industrial Relations in 2010." Journal of Industrial Relations, 53 (3): 337-352.

3. Baird, M. 2005. "Parental leave in Australia: The role of the industrial relations system." Law in Context, 23 (1): 45-64.

4. Baird, M. 2003. "Paid maternity leave: The good, the bad, the ugly." Australian Bulletin of Labour, 29 (1): 97-109.

5. Baird, M. and Constantin, A. 2016. "Analysis of the impact of the Government's MYEFO cuts to Paid Parental Leave." Commissioned by Fair Agenda. https://d3n8a8pro7vhmx.cloudfront.n et/fairagenda/pages/294/attachments Loriginal/1477524925/Analysis of im pact of PPL cuts WWRG 27102016 Final.pdf?1477524925

6. Baird, M., Frino, E., and Williamson, S. 2009. "Paid Maternity and Paternity Leave and the Emergence of "Equality Bargaining" in Australia: An Analysis of Enterprise Agreements 2003-2007." Australian Bulletin of Labour, 35 (4): 671-691.

7. Department of Social Services (DSS). 2014. Department of Social Services Annual Report 20132014. DSS Canberra. Australian Government.

8. Department of Social Services (DSS). 2015. Department of Social Services Annual Report 20142015. DSS Canberra. Australian Government.

9. Department of Social Services (DSS). 2016. Department of Social Services Annual Report 20152016. DSS Canberra. Australian Government.

10. Department of Social Services (DSS). 2017. Department of Social Services Annual Report 20162017. DSS Canberra. Australian Government.
11. Department of Social Services (DSS). 2018. Department of Social Services Annual Report 20172018. DSS Canberra. Australian Government.

12. Department of Social Services (DSS). 2019. Department of Social Services Annual Report 20182019. DSS Canberra. Australian Government.

13. Department of Social Services (DSS). 2020. Department of Social Services Annual Report 20192020. DSS Canberra. Australian Government.

14. Department of Families, Housing, Community Services and Indigenous Affairs (FAHCSIA). 2012. Annual Report 2011-2012. Department of Families, Housing, Community Services and Indigenous Affairs, Canberra. Australian Government.

15. Department of Families, Housing, Community Services and Indigenous Affairs (FAHCSIA). 2013. Annual Report 2012-2013. Department of Families, Housing, Community Services and Indigenous Affairs, Canberra. Australian Government.

16. Glezer, H. 1988. Maternity Leave in Australia: Employee and Employer Experiences: Report of a Survey, Australian Institute of family Studies.

17. Haas, L. and Hwang, P.C. 2019. "Policy is not enough - the influence of the gendered workplace on fathers' use of parental leave in Sweden." Community, Work \& Family, 22 (1): 58-76. DOI: 10.1080/13668803.2018.1495616

18. Human Rights and Equal Opportunity Commission. 2002a. Valuing Parenthood: Options for a paid maternity leave scheme. HREOC.

19. Human Rights and Equal Opportunity Commission. 2002b. A Time to Value: Proposal for a national paid maternity leave scheme. HREOC.

20. Koslowski, A., Blum, S., Dobrotić, I., Kaufman, G., and Moss, P. 2020. International Review of Leave Policies and Research 2020. International Network on Leave Polices and Research.

http://www.leavenetwork.org/lp_and_r_reports/. Accessed 02/09/2021

21. Martin, B., Baird, M., Brady, M., Broadway, B., Hewitt, B., Kalb, G., Strazdins, L., Tomaszewski, W., 
Zadoroznyj, M., Baxter, J., Chen, R., Foley, M., McVicar, D., Whitehouse, G., and Xiang, N. 2014b. Paid Parental Leave Evaluation: Final Report. Report prepared by the Institute for Social Science Research.

https://www.dss.gov.au/sites/default/files /documents/03 2015/finalphase4 report 6 march 2015 0.pdf

Accessed 01/09/2021

22. Martin, B., Hewitt, B., Yerkes, M., Xiang, N., Rose J., and Coles L. 2014a. Paid Parental Leave Evaluation: Phase 3 Report. Report prepared by the Institute for Social Science Research.

https://www.dss.gov.au/sites/default/files /documents/03 2015/finalphase3report 6 march 2015 0.pdf

Accessed 01/09/2021

23. Martin, B., Yerkes, M., Hewitt, B., Baird, M., Jones, A., Rose, E., Rose, J., Davis, K., Coles, L., Heron, A., and Xiang N. 2013. Paid Parental Leave Evaluation: Phase 2 Report. Report prepared by the Institute for Social Science Research.

https://www.dss.gov.au/sites/default/files

/documents/12 2013/paid parental leave evaluation.pdf

Accessed 01/09/2021.

24. Martin, B., Hewitt, B., Baird, M., Baxter, J., Heron, A., Whitehouse, G., Zadoroznyj, M., Xiang, N., Broom, D., Connelly, L., Jones, A., Kalb, G., McVicar, D., Strazdins, L., Walter, M., Western, M., and Wooden, M. 2012. Paid Parental Leave evaluation: Phase 1 Report.

https://www.dss.gov.au/sites/default/files /documents/06 2012/op44.pdf

Accessed 01/09/2021

25. Mather, J. 2015. “Federal Budget 2015: Ministers under fire over 'double dipping' parental leave row." Financial Review, Melbourne, 14 May. https://www.afr.com/policy/economy/federalbudget-2015-ministers-under-fire-over-doubledipping-parental-leave-row-20150514-gh18fg Accessed 24/02/2021
26. O’Brien, M. 2009. “Fathers, Parental Leave Policies, and Infant Quality of Life: International Perspectives and Policy Impact." Annals of the American Academy of Political and Social Science, 624 (1): 190-213.

25. Productivity Commission. 2013. Annual Report 2012-13. Productivity Commission, Canberra.

26. Productivity Commission. 2009. Paid Parental Leave: Support for Parents with Newborn Children. Report no. 47, Productivity Commission, Canberra.

27. Ray, R., Gornick, J., and Schmitt, J. 2010. "Who cares? Assessing generosity and gender equality in parental leave policy designs in 21 countries". Journal of European Social Policy, 20 (3): 196-216.

28. Shaver, S. 1999. “Gender down under: Welfare restructuring in Australia and Aotearoa / New Zealand." Social Policy \& Administration 33 (5): 586603.

29. Spallek, M., Haynes, M., Baxter, J., and Kapelle, N. 2020. "The value of administrative data for longitudinal social research: a case study investigating income support receipt and relationship separation in Australia." International Journal of Social Research Methodology, 23 (5): 467-481. DOI: 10.1080/13645579.2019.1707984

30. Taylor, M. 2018. Parental leave pay and paid maternity leave: should entitlement be tied? Working Paper no. 7/2018., Centre for Social Research and Methods, Australian National University.

31. Whitehouse, G. and Nakazato, H. 2021. "Dimensions of social equality in paid parental leave policy design: comparing Australia and Japan". Social Inclusion, 9 (2): 288-299. doi: 10.17645/si.v9i2.3863

32. Whitehouse, G., Baird, M., Diamond, C., and Soloff, C. 2007. "Parental leave in Australia': beyond the statistical gap." Journal of Industrial Relations, 49 (1): 103-112.

33. Whitehouse, G., Baird, M., Diamond, C., and Hosking, A. 2006. The Parental Leave in Australia Survey: November 2006. Report, School of Political 
Science and International Studies, University of Queensland.

34. Workplace Gender Equality Agency. 2020. WGEA Data Explorer. Workplace Gender Equality Agency. https://data.wgea.gov.au/comparison/?id1=94\&id2=27 Accessed 22/02/2021

\section{Legislation}

Paid Parental Leave Act 2010 (Cth). 